\title{
Chapter
}

\section{CANCER TARGETING STRATEGIES OF NANOMATERIALS}

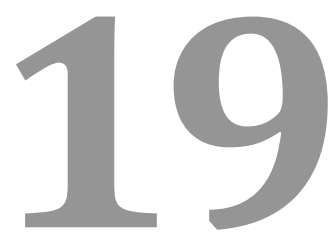

\section{Jeong-Hun Kang1, Riki Toita², Takahito Kawano ${ }^{3}$,}

and Masaharu Murata ${ }^{3,4^{*}}$

${ }^{1}$ Division of Biopharmaceutics and Pharmacokinetics, National Cerebral and Cardiovascular Center Research Institute, 5-7-1 Fujishiro-dai, Suita, Osaka 565-8565, Japan

2 Department of Biomaterials, Faculty of Dental Science, Kyushu University, 3-1-1 Maidashi, Higashi-Ku, Fukuoka 812-8582, Japan ${ }^{3}$ Innovation Center for Medical Redox Navigation, Kyushu University, 3-1-1 Maidashi, Higashi-ku, Fukuoka, Japan

${ }^{4}$ Department of Advanced Medical Initiatives, Faculty of Medical Sciences, Kyushu University, 3-1-1 Maidashi, Higashi-ku, Fukuoka 812-8582, Japan 


\section{Contents}

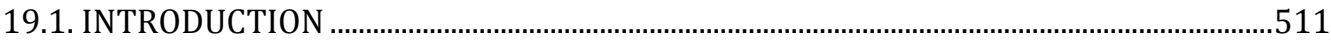

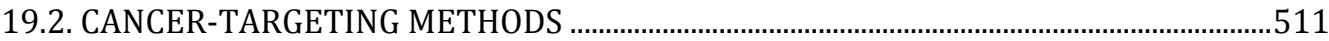

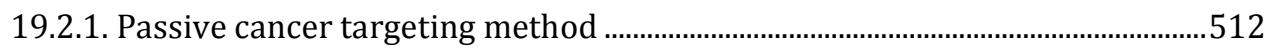

19.2.1.1. Characteristics of nanomaterials that influence EPR ............................513

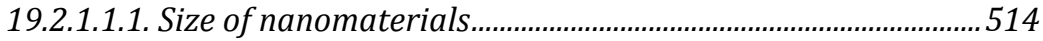

19.2.1.1.2. Charge of nanomaterials ..........................................................514

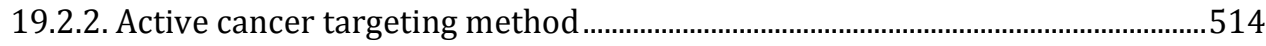

19.2.2.1. Overexpressed receptors in cancer cells................................................514

19.2.2.1.1. Nanomaterials targeting overexpressed receptors in cancer cells....................................................................................515

19.2.2.2. Overexpressed cellular signals in cancer cells.......................................517

19.2.2.2.1. Nanomaterials targeting overexpressed cellular signals

(proteases and protein kinases) in cancer cells ......................517

19.2.2.3. Nanomaterials targeting hypoxic cancer regions...................................518

19.3. CLINICAL APPLICATIONS OF NANOMATERIALS IN CANCER TREATMENT..............519

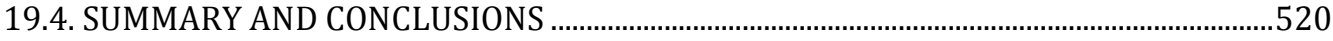

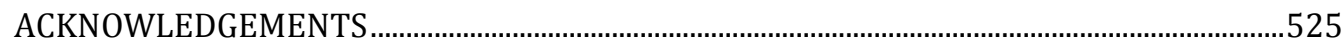

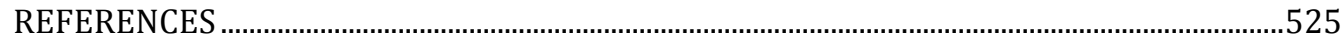




\subsection{INTRODUCTION}

Cancer (a malignant tumor) is the leading cause of disease-related death, and 8.2 million cancer-related deaths were reported by the World Health Organization in 2012 [1]. Among cancer types, the most common causes of cancer death are lung, liver, and stomach cancers $[1,2]$. Surgery, chemotherapy, immunotherapy, and radiotherapy, either alone or in combination, can be used to treat cancer [3-5]. In recent years, there has been increasing interest in targeted delivery of therapeutic molecules (e.g., genes, drugs, or proteins), which has several advantages over other forms of treatment: (1) enhanced therapeutic efficacy, (2) avoidance of undesired side effects caused by the delivery of therapeutic molecules to normal (healthy) cells; and (3) reduction of the efficacious dose of therapeutic molecules [6,7].

Cancer-targeted delivery systems for therapeutic molecules can be grouped into three categories: viral nanomaterials (e.g., inactivated retroviruses, adenoviruses, adeno-associated viruses, and herpes simplex viruses), non-viral nanomaterials (e.g., synthetic polymers and liposomes), and bacterial carriers (e.g., Clostridium, Salmonella, and Bifidobacterium). Viral nanomaterials show high transfection efficiency, but have clinical safety issues (e.g., immune responses) that must be solved before their use in clinical trials. Furthermore, because viral nanomaterials themselves do not have the ability to target cancer cells, their conjugation to cancer-specific ligands or promoters are required for cancer targeting [8-10]. Non-viral nanomaterials have several advantages such as low pathogenicity and that they easily can be mass-produced, but their disadvantages are low transfection efficiency and low cancer targeting capabilities; thereby, also requiring the use of cancer-specific ligands [11,12]. Anaerobic bacteria are mainly used as bacterial carriers for the delivery of therapeutic molecules to hypoxic cancer cells. They have high transfection efficiency, but also cause clinical safety problems such as inflammation and immune responses [13].

In this chapter, we focus on cancer targeting methods using nanomaterials for cancer cell-targeted therapy.

\subsection{CANCER-TARGETING METHODS}

Cancer targeting by nanomaterials is accomplished by either passive or active targeting. In the case of active targeting, nanomaterials typically recognize or respond to overexpressed receptors, overexpressed intracellular signals, or hypoxic regions in cancer cells and tissues (Table 1). 
Table 1. Advantages and disadvantages of cancer targeting methods for clinical applications [6]

\begin{tabular}{|c|c|c|c|c|c|c|c|}
\hline \multirow{2}{*}{\multicolumn{2}{|c|}{$\begin{array}{l}\text { Passive cancer } \\
\text { targeting method, the } \\
\text { enhanced } \\
\text { permeability and } \\
\text { retention effect (EPR) }\end{array}$}} & \multicolumn{6}{|c|}{ Active cancer targeting method } \\
\hline & & \multicolumn{2}{|c|}{$\begin{array}{l}\text { Nanomaterials } \\
\text { targeting } \\
\text { overexpressed } \\
\text { receptors in cancer } \\
\text { cells }\end{array}$} & \multicolumn{2}{|c|}{$\begin{array}{c}\text { Nanomaterials } \\
\text { targeting } \\
\text { overexpressed cellular } \\
\text { signals (proteases and } \\
\text { protein kinases) in } \\
\text { cancer cells }\end{array}$} & \multicolumn{2}{|c|}{$\begin{array}{l}\text { Nanomaterials } \\
\text { targeting hypoxic } \\
\text { cancer regions }\end{array}$} \\
\hline 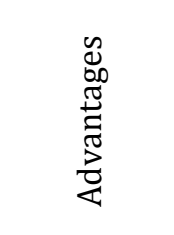 & 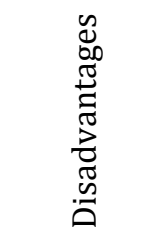 & 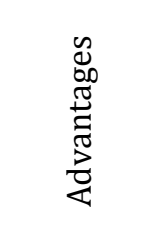 & 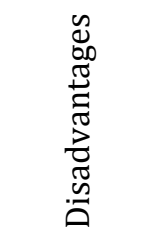 & 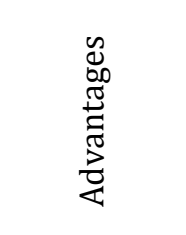 & 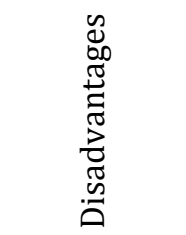 & 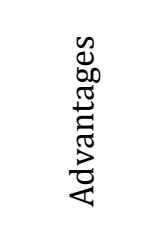 & 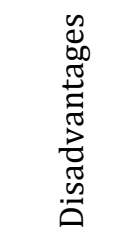 \\
\hline $\begin{array}{l}\text { 1. High } \\
\text { specificity } \\
\text { for solid } \\
\text { cancers } \\
2 . \\
\text { Applicable } \\
\text { to various } \\
\text { types of } \\
\text { drugs or } \\
\text { nanomateri } \\
\text { als } \\
\text { 3. Reduced } \\
\text { side effects }\end{array}$ & $\begin{array}{l}\text { 1. Low } \\
\text { EPR effect } \\
\text { in poorly } \\
\text { vasculariz } \\
\text { ed regions } \\
2 . \text { Low } \\
\text { therapeuti } \\
\text { c value in } \\
\text { spreading } \\
\text { and } \\
\text { metastatic } \\
\text { cancers }\end{array}$ & $\begin{array}{l}\text { 1. High } \\
\text { specificit } \\
\text { y for } \\
\text { cancers } \\
2 . \\
\text { Reduced } \\
\text { side } \\
\text { effects } \\
3 . \\
\text { Enhanced } \\
\text { therapeut } \\
\text { ic efficacy }\end{array}$ & $\begin{array}{l}\text { 1. Lack of } \\
\text { ligands } \\
\text { respondin } \\
\text { g to } \\
\text { overexpre } \\
\text { ssed } \\
\text { receptors } \\
2 . \\
\text { Different } \\
\text { activity } \\
\text { levels of } \\
\text { receptors } \\
\text { between } \\
\text { patients }\end{array}$ & $\begin{array}{l}\text { 1. High } \\
\text { specificity } \\
\text { for cancers } \\
\text { 2. Reduced } \\
\text { side effects } \\
\text { 3. Enhanced } \\
\text { therapeutic } \\
\text { efficacy }\end{array}$ & $\begin{array}{l}\text { 1. Lack of } \\
\text { selective } \\
\text { peptides or } \\
\text { proteins } \\
\text { responding } \\
\text { to } \\
\text { overexpress } \\
\text { ed cellular } \\
\text { signals } \\
\text { 2. Different } \\
\text { activity } \\
\text { levels of } \\
\text { cellular } \\
\text { signals } \\
\text { between } \\
\text { patients }\end{array}$ & $\begin{array}{l}\text { 1. High } \\
\text { specificit } \\
\text { y for } \\
\text { hypoxic } \\
\text { cancers } \\
2 . \\
\text { Enhanced } \\
\text { therapeut } \\
\text { ic efficacy }\end{array}$ & $\begin{array}{c}\text { 1. Lack } \\
\text { of useful } \\
\text { vectors } \\
2 . \\
\text { Clinical } \\
\text { safety } \\
\text { issues } \\
\text { and risk } \\
\text { of side } \\
\text { effects }\end{array}$ \\
\hline
\end{tabular}

\subsubsection{Passive cancer targeting method}

Cancer cells require oxygen and nutrients to promote their growth and progress. Therefore, the formation of new blood vessels via angiogenesis is essential for cancer growth and metastasis. Cancer angiogenesis is trigged by multiple pro-angiogenic factors, including vascular endothelial growth factor (VEGF), angiopoietins, basic fibroblast growth factor (bFGF) and cytokines [interleukin-1 (IL-1), and tumor necrosis factor $\alpha$ (TNF $\alpha$ )]. In addition to chemoattractants, integrins $\left(\alpha_{v} \beta_{3}\right.$ and $\left.\alpha_{5} \beta_{1}\right)$, receptors (VEGF receptors), and circulating bone marrow-derived cells $\left(\mathrm{F} 4 / 80^{+} \mathrm{CD} 11 \mathrm{~b}^{+}\right.$macrophages and $\mathrm{Gr} 1^{+} \mathrm{CD} 11 \mathrm{~b}^{+}$neutrophils) directly and/or indirectly participate in the angiogenic process of cancer $[14,15]$. Blood vessels near cancer cells are often dilated, leaky, tortuous, and heterogeneous. 
The passive cancer targeting method is based on the EPR effect that is characteristic of blood vessels near cancer cells. Therefore, when nanomaterials or anti-cancer drugs are injected into the blood stream, they accumulate in cancer cells through these dilated, leaky, tortuous, and heterogeneous blood vessels near cancer tissues when compared with normal tissues that have blood vessels showing a well-organized and functional structure (Figure 1) [16]. However, the vessel structure and pore size of blood vessels within individual cancer types is different [17]. Thus, EPR-based cancer therapy using nanoparticles can exhibit different therapeutic efficacies depending upon the cancer type. The synthesis of optimized nanomaterials for each target cancer type is essential for efficient EPR-based cancer therapy.

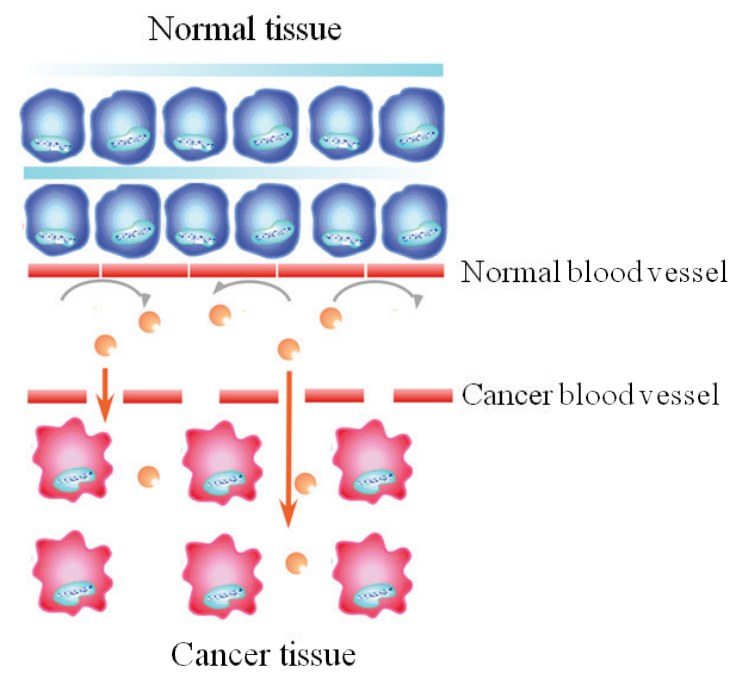

Figure 1. Schematic illustration of the EPR effect. Unlike normal blood vessels showing a well-organized and functional structure, cancer blood vessels are leaky, tortuous, and heterogeneous. Nanomaterials injected into the blood stream can pass through these cancer blood vessels and tend to accumulate in cancer tissues, but none or very few pass through normal blood vessels that have a well-organized and functional structure.

Figure 1 has been reproduced from a previous publication [6].

\subsubsection{Characteristics of nanomaterials that influence EPR}

Several nanomaterial characteristics might affect the EPR effect, such as size [17-19], surface charge [17-19], hydrophobicity (high hydrophobicity increases the affinity for the cell membrane) [20], flexibility (high flexibility leads to rapid renal clearance) [18,19], and shape (spheres have a higher uptake by macrophages as compared with rods) $[18,19]$. Among these factors, 
size and surface charge of nanomaterials may be the most important factors influencing the EPR effect.

\subsection{Size of nanomaterials}

Nanomaterials smaller than $5.5 \mathrm{~nm}$ mainly undergo kidney excretion and those larger than $8 \mathrm{~nm}$ are rapidly cleared through the reticuloendothelial system organs (liver and spleen) [18,21]. Normal blood vessels can permeate smaller nanomaterials $(<20 \mathrm{~nm})$, but blood vessels near cancer cells are permeable to nanomaterials of $<400 \mathrm{~nm}$ in diameter [17,19,22]. Indeed, poly(ethylene glycol) (PEG)-liposomes of $400 \mathrm{~nm}$ in diameter can penetrate into the cancer interstitium, but those of $600 \mathrm{~nm}$ are excluded from extravascular spaces [22]. However, the most efficient EPR-based therapy might be obtained using nanomaterials between $10-200 \mathrm{~nm}$ in diameter [23]. A previous study reported that nanomaterials with a molecular weight (MW) greater than $40 \mathrm{kDa}$ exhibited a high EPR effect [24]. However, other studies suggested that the EPR effect did not depend on the molecular weight (MW) of nanomaterials $[22,25]$. Therefore, the size of nanomaterials may be more important for efficient EPR than is the MW.

\subsection{Charge of nanomaterials}

Negatively charged nanomaterials are taken up rapidly by phagocytes (macrophages) and are degraded or discharged from the body. Nanomaterials with high positive charges can bind to blood proteins or to the surface of blood vessels, resulting in rapid kidney excretion and low accumulation in cancer cells $[17,19]$. The uptake of nanomaterials $(150 \mathrm{~nm})$ by macrophages was increased in the order of $-40>-25>-15 \mathrm{mV}$ negative surface charge and $+35>+25>+15 \mathrm{mV}$ positive surface charge [26]. Therefore, neutral or weakly positive-charged nanomaterials are more efficient for EPR compared with strong negatively-charged or positively-charged nanomaterials.

\subsubsection{Active cancer targeting method}

\subsubsection{Overexpressed receptors in cancer cells}

Cancer cells overexpress numerous receptors. The binding of ligands to overexpressed target receptors plays a key role in the growth, survival, metastasis, angiogenesis, and apoptosis of cancer cells (Figure 2). Examples of this are the binding of EGF and FGF to growth factor receptors (tyrosine kinase receptors) [27,28], and prostaglandin $\mathrm{E}$ and lysophosphatidic acid to G-protein-coupled receptors [29]. However, TNF $\alpha$ and TNF-related apoptosis inducing ligand (TRAIL) can stimulate apoptosis of cancer cells by binding to death receptors. However, death receptors and their downstream signals (e.g., caspases) are often suppressed in cancer cells [30-32]. Therefore, nanomaterials recognizing overexpressed receptors in cancer cells might be useful for cancer-targeted therapy. 


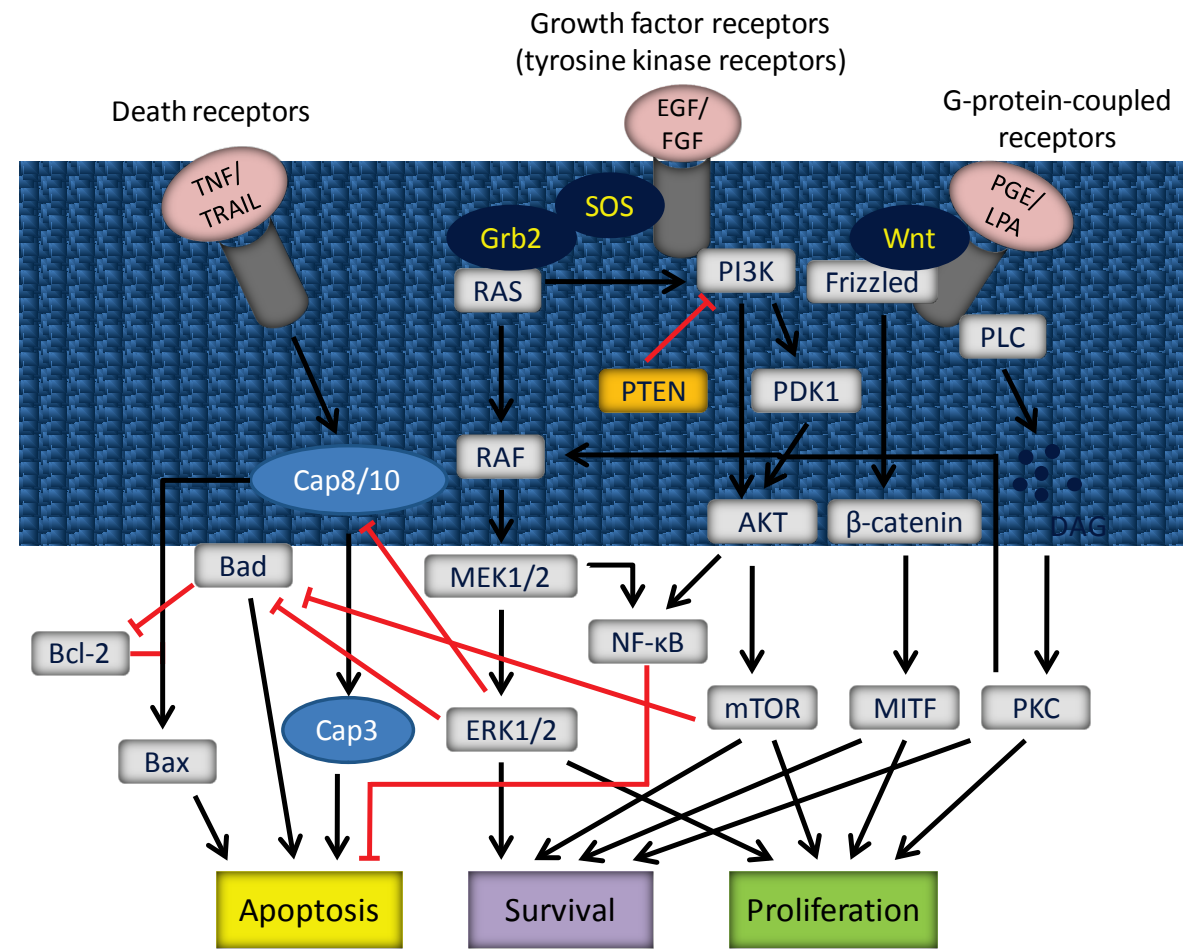

Figure 2. Signal transduction pathways are different in cancer cells compared with normal cells. Cancer cells overexpress receptors (growth factor receptors and G-protein-coupled receptors) and intracellular signaling molecules (ras/raf/mek/erk and pi3k/akt/mtor) that are related to cell survival and proliferation. However, apoptosis-related receptors (death receptors) and intracellular signals (caspases) are suppressed. Therefore, nanomaterials targeting or responding to overexpressed receptors or cellular signals of cancer cells can be useful for cancer cell-targeted therapy. Figure 2 has been modified from previous publications [59,92].

\subsection{Nanomaterials targeting overexpressed receptors in cancer cells}

Many receptor-specific ligands (aptamers, proteins, peptides, and antibodies) have been reported to be useful materials for targeting overexpressed receptors on cancer cells. Although transferrin and folate, which recognize transferrin receptor (TfR) and folate receptor, respectively, are extensively used to target various cancer cells, most nanomaterials containing receptor-specific ligands were identified by using limited numbers of cancer cells that overexpressed target receptors (Table 2). For instance, although targeting and therapeutic efficacy of folate-conjugated nanomaterials have been investigated using 9L / LacZ rat gliosarcoma cells [33], IGROV-1 human ovarian cancer cells [34], SKOV-3 human ovarian cancer cells [35], and B16 mouse melanoma cells 
[36], the most commonly used cells are KB human epidermoid carcinoma and HeLa human epidermoid carcinoma cells, because they have an especially high overexpression of folate receptors [37-43]. It is important to note that receptor expression may vary according to the cancer cell type. For example, the antisense delivery efficiency of TfR-targeted, protamine-containing lipid nanomaterials was in the order of K562 > MV4-11 > Raji human leukemia cells, which was directly related to the TfR expression level. Thus, the higher the TfR expression, the greater the down-regulation of the target gene by nanomaterials [44].

Several receptor-specific peptides in Table 2 have been investigated, such as homing peptides identified from various library methods (the phage display peptide library method) (for review, see [45-47]). Nanomaterials containing these homing peptides can be used for cancer cell-targeted therapy. For example, the small heat shock protein 16.5-derived nanocage conjugated to a human hepatocellular carcinoma cell-specific peptide SP94 (SFSIIHTPILPL) was identified by an in vivo phase display method, and achieved selective targeting to HepG2 and HuH-7 human hepatocellular carcinoma cells, but not to HeLa cells or RLN-8 rat hepatocytes [48].

Double-targeted nanomaterials conjugated to dual-ligands, such as transferrin and folate [49], cyclic RGD (cRGD) and transferrin [50], glucose and folate [51], and RGD and IL-13 peptide (CGEMGWVRC) [52], have been developed to increase therapeutic efficacy against target cancer cells or to target specific cancer cells. Gold nanoparticles conjugated to folate and glucose showed a higher uptake by human epidermoid carcinoma (KB) cells than did gold nanomaterials conjugated to either folate or glucose alone [51]. Similarly, when transferrin and folate were linked to PEG-phosphatidylethanolamine, the transfection efficiency in HepG2 human hepatocellular carcinoma cells was higher for the conjugate than for the single ligand-modified nanomaterials [49]. Furthermore, nanomaterials linked with RGD and IL-3 peptide [52], and cRGD and transferrin [50] successfully targeted human umbilical vein endothelial and C6 rat glioma cells, and human umbilical vein endothelial and HeLa human epidermoid carcinoma cells, respectively.

In contrast, several studies have suggested that cancer-specific ligandconjugated nanomaterials did not preferentially localize to cancer tissues in comparison with non-conjugated nanomaterials [53-55]. In these studies, despite the lack of change in cancer localization, ligand-conjugated nanomaterials showed enhanced uptake by cancer cells compared with non-conjugated nanomaterials, indicating that the increased therapeutic efficacy against cancer cells by ligand-conjugated nanomaterials was caused by increased uptake by cancer cells rather than by their localization to cancer cells [53-55]. 


\subsubsection{Overexpressed cellular signals in cancer cells}

Living cells contain numerous intracellular signal transduction pathways that play a key role in cell growth, differentiation, proliferation, and apoptosis. These signal pathways are tightly regulated and function normally in healthy cells. However, in cancer cells, many signal pathways related to cellular survival and proliferation are overexpressed, such as the RAS/RAF/MEK/ERK and PI3K/AKT/mTOR pathway. In some cases, apoptosis-related signal pathways are suppressed, such as the death receptor-mediated pathways (Figure 2). Therefore, nanomaterials that could respond to these overexpressed intracellular signals could also be used for cancer-targeted therapy.

19.2.2.2.1. Nanomaterials targeting overexpressed cellular signals (proteases and protein kinases) in cancer cells

Cellular signal transduction pathways often are stimulated or suppressed through phosphorylation by protein kinases, or by dephosphorylation or cleavage by proteases. Phosphorylation reactions mediated by protein kinases add a phosphate group from adenosine triphosphate to the phosphorylation sites (serine, threonine, and tyrosine) [56,57] located on proteins. Nanomaterials that recognize overexpressed protein kinases are related to the phosphorylation reaction. Phosphorylation of nanomaterials containing target peptides can add two anionic charges of the phosphate to target peptide substrates, thereby weakening electrostatic interactions in the nanomaterials. For example, protein kinase $\mathrm{C}$ (PKC) $\alpha$ and protein kinase A (PKA) are overexpressed in several cancer cells, such as breast cancer, lung cancer, melanoma, ovarian cancer, and prostate cancer, but are expressed at very low levels in normal cells or tissues [58-60]. Nanomaterials conjugated to PKC $\alpha$ (FKKQGSFAKKK)- or PKA (ALRRSLG)-specific peptides showed a higher targeting efficacy to cancer cells or tissues than to normal cells or tissues [61-66].

As mentioned in 19.2.2.1., caspase activation in cancer cells is very low, but can be stimulated by the activation of death receptors through stimulators such as TNF $\alpha$ and TRAIL. Caspases induce cell apoptosis by cleavage of their target peptides [30-32]. In a recent study, doxorubicin conjugated to a caspase-3specific peptide (DEVD) was efficiently cleaved in apoptotic regions of cancer cells induced by radiation exposure, leading to efficient inhibition of cancer growth, with low toxicity in normal tissues [67].

Several protease cleavable nanoparticles have been developed for cancer cell-targeted therapy. Matrix metalloproteinases (MMPs) (MMP-2, -9, and -12) are known as cancer-associated proteases, and participate in the progression of several cancer mechanisms, including migration, invasion, metastasis, and angiogenesis [68,69]. MMP-specific peptides (PVGLIG and GPLGIAGQ for MMP-2) can be selectively cleaved by MMPs that are overexpressed in cancer 
cells. Exploiting these functions of MMPs, conjugates of MMP-cleavage peptides and anticancer drugs can be useful for cancer cell-targeted therapies [70-73]. For example, a self-assembled nanoparticle containing PEG 2000-paclitaxelMMP-2 peptide (GPLGIAGQ) exhibited a higher anticancer efficacy in vitro and in vivo than did free paclitaxel [70]. Furthermore, nanocages conjugated with a MMP-2-binding peptide (CTTHWGFTLC) showed selective uptake into MMP-2 overexpressing cancer cells [74].

\subsubsection{Nanomaterials targeting hypoxic cancer regions}

EPR-mediated or ligand-mediated targeting methods generally have a low targeting efficacy for hypoxic tumor regions. Their therapeutic efficacy against hypoxic tumor cells is also dramatically reduced because of the limited delivery of therapeutic agents to cancer cells and the induction of drug resistance $[75,76]$.

Hypoxia-inducible factor- $1 \alpha$ (HIF- $1 \alpha$ ) is an attractive therapeutic target because it is a key regulator of the hypoxic environment and is related to drug resistance and cancer metastasis [76]. Therefore, suppression of HIF- $1 \alpha$ expression leads to an increase in therapeutic efficacy against hypoxic cancer cells. Several nanomaterials that bind to or contain HIF- $1 \alpha$ siRNA or antisense oligonucleotides have been developed and have exhibited a high therapeutic efficacy for hypoxic cancer cells and increased inhibitory efficacy against cancer metastasis [77-80].

For hypoxic cancer cell-targeted therapy, several nanomaterials (mainly viral nanomaterials) incorporating hypoxia-responsive promoters that are specifically expressed in hypoxic cancers, have a high specificity and gene expression for hypoxic cancer cells [81,82]. Furthermore, nanomaterials containing hypoxia-responsive agents (2-nitroimidazole), which can be highly sensitive to hypoxia, are suitable for hypoxic tumor cell-targeted therapy $[83,84]$.

Another strategy for hypoxic cancer cell-targeted therapy is the use of anaerobic bacteria (e.g., Salmonella and Clostridium spp.). Anaerobic bacteria themselves have the capacity to inhibit the growth of cancer cells and also can increase therapeutic efficacy in combination with anticancer molecules or radiation therapy [13,85-88]. Salmonella and Clostridium are pathogenic bacteria and therefore cause clinical safety problems such as inflammation and immune responses. To overcome these problems, non-pathogenic anaerobic bacteria (e.g. Bifidobacterium sp.) [89] and nonpathogenic or attenuated bacteria $[90,91]$ are being developed as bacterial vectors to target hypoxic cancers. 


\subsection{CLINICAL APPLICATIONS OF NANOMATERIALS IN CANCER TREATMENT}

Nanomaterial-anticancer drug complexes are most commonly used in cancer clinical trials. For example, liposomes loaded with anticancer drugs, such as doxorubicin and daunorubicin, have been approved by the U.S. Food and Drug Administration for the treatment of several cancers, such as ovarian and metastatic breast and human immunodeficiency virus-related Kaposi sarcoma (see [93-95] for review). In cancer clinical trials, the use of PEG-conjugated liposomes (rather than PEG-free liposomes) may be a more efficient way to increase therapeutic effects of anticancer drugs, because of their prolonged blood circulation time and enhanced drug accumulation in cancer cells [94,95]. In addition to liposome-drug complexes, several nanomaterial-drug complexes are currently undergoing clinical trials in cancer, such as the polymer-drug conjugate of paclitaxel and poly(L-glutamic acid) (also known as paclitaxel poliglumex, Xyotax, and CT-2103) for the treatment of non-small cell lung cancer [96,97], cyclodextrin-PEG micelle with camptothecin (also known as CRLX-101) for advanced (metastatic and / or unresectable) solid malignancies [98] and PEG-irinotecan conjugate (also known as etirinotecan pegol and NKTR-102) for advanced breast cancer [99]. Targeting delivery of these nanomaterial-drug complexes to cancer cells is based on the EPR effect.

On the other hand, there are very few reports on cancer clinical trials using nanomaterial-gene complexes. Recently, results of a phase I clinical trial using a complex of the human tumor suppressor gene p53 with a liposomal nanomaterial (SGT-53) employing an anti-transferrin receptor single-chain antibody fragment (scFv) as the targeting molecule were reported. The trial supplied evidence of targeted cancer delivery of systemically dosed SGT-53 to metastatic lesions. Furthermore, SGT-53 was well-tolerated and exhibited anticancer activity [100]. Similarly, in a phase I clinical trial using a small interfering RNA targeting the M2 subunit of ribonucleotide reductase (RRM2) complexed with nanomaterials containing a cyclodextrin-containing polymer, a PEG, and human transferrin, the complex efficiently reduced the specific RRM2 messenger RNA and the RRM2 protein levels in cancer tissues [101]. Targeting of nanomaterial-gene complexes containing scFv [100] or transferrin [101] to cancers is based on the active cancer targeting method, and takes advantage of the overexpression of transferrin receptor in cancer cells. 


\subsection{SUMMARY AND CONCLUSIONS}

For cancer cell-targeted delivery of therapeutic molecules, several delivery systems, including viral or non-viral nanomaterials, and anaerobic bacterial carriers, have been developed and utilized for in vivo or ex vivo / in vitro applications. Cancer targeting by nanomaterials is accomplished by both passive and active cancer targeting. Passive targeting methods based on the EPR effect exhibit low therapeutic efficacy in poorly vascularized regions and in spreading and metastatic cancers. Active cancer targeting is based on the recognition or response to overexpressed receptors, overexpressed intracellular signals, and hypoxic regions in cancer cells and tissues. However, a lack of cancer targeting materials (ligands and peptide substrates responding to activated receptors and intracellular signals, respectively) and different activity levels of receptors and intracellular signals between patients may be a serious obstacle to be overcome for the use of nanomaterials based on the active cancer targeting method.

Table 2. Receptor-specific ligands used for the development of cancer cell-targeted nanomaterials

\begin{tabular}{|c|c|c|c|}
\hline Ligands & Receptors & Target cancer cells & Refs. \\
\hline \multicolumn{4}{|l|}{ Antibodies (Abs) } \\
\hline Anti-CD20 Ab (Mabthera) & CD20 receptor & Daudi lymphoma cells & [102] \\
\hline Anti-CD71 Ab & TfR & $\begin{array}{l}\text { PC-3 human prostate } \\
\text { cancer cells }\end{array}$ & [103] \\
\hline \multirow[t]{2}{*}{ Anti-DR5 Ab } & $\begin{array}{l}\text { Death receptor } 5 \\
\text { (DR5; also known as } \\
\text { TRAIL-receptor 2) }\end{array}$ & $\begin{array}{l}\text { HCT116 human colon } \\
\text { cancer cells }\end{array}$ & [104] \\
\hline & & $\begin{array}{l}\text { A375 human melanoma } \\
\text { cells }\end{array}$ & [105] \\
\hline \multirow[t]{2}{*}{ Anti-HER2 Ab (Herceptin) } & $\begin{array}{l}\text { Human epidermal } \\
\text { growth factor } \\
\text { receptor 2 (HER2) }\end{array}$ & $\begin{array}{l}\text { SKOV-3 human ovarian } \\
\text { cancer cells }\end{array}$ & [102] \\
\hline & & $\begin{array}{l}\text { SK-BR-3 human breast } \\
\text { cancer cells }\end{array}$ & [106] \\
\hline Anti-Met Ab & $\begin{array}{l}\text { Hepatocyte growth } \\
\text { factor receptor } \\
\text { (HGFR; also known as } \\
\text { c-Met or Met) }\end{array}$ & $\begin{array}{l}\text { A549 human lung cancer } \\
\text { and MKN45 human } \\
\text { gastric cancer cells }\end{array}$ & [107] \\
\hline $\begin{array}{c}\text { Single chain variable } \\
\text { fragment anti-EGFR Ab } \\
\text { (ScFvEGFR) }\end{array}$ & EGFR & $\begin{array}{l}\text { H292 human lung cancer } \\
\text { cells }\end{array}$ & [108] \\
\hline $\begin{array}{l}\text { Transferrin receptor Ab } \\
\text { (OKT9) }\end{array}$ & TfR & $\begin{array}{l}\text { Ramos human Burkitt's } \\
\text { lymphoma cells }\end{array}$ & [109] \\
\hline
\end{tabular}




\begin{tabular}{|c|c|c|c|}
\hline Ligands & Receptors & Target cancer cells & Refs. \\
\hline \multicolumn{4}{|l|}{ Aptamers } \\
\hline Sgc8 DNA aptamer & $\begin{array}{l}\text { PTK7 (an orphan } \\
\text { tyrosine kinase } \\
\text { receptor) }\end{array}$ & $\begin{array}{l}\text { CEM lymphoblastic } \\
\text { leukemia cells }\end{array}$ & [110] \\
\hline GL21.T aptamer & $\begin{array}{l}\text { Axl receptor (a } \\
\text { tyrosine kinase } \\
\text { receptor) }\end{array}$ & $\begin{array}{l}\text { A549 human lung cancer } \\
\text { and U87 human glioma } \\
\text { cells }\end{array}$ & [111] \\
\hline GS24 aptamer & $\mathrm{TfR}$ & $\begin{array}{c}\text { B16 mouse melanoma } \\
\text { cells }\end{array}$ & [112] \\
\hline \multicolumn{4}{|l|}{ Proteins (glycoproteins) } \\
\hline Asialofetuin & $\begin{array}{l}\text { Asialoglycoprotein } \\
\text { receptor }\end{array}$ & $\begin{array}{l}\text { HepG2 human } \\
\text { hepatocellular } \\
\text { carcinoma cells }\end{array}$ & [113] \\
\hline \multirow[t]{3}{*}{ EGF } & EGFR & $\begin{array}{c}\text { H22 mouse } \\
\text { hepatocellular } \\
\text { carcinoma cells }\end{array}$ & [114] \\
\hline & & $\begin{array}{l}\text { MDA-MB-468 human } \\
\text { breast cancer cells }\end{array}$ & [115] \\
\hline & & $\begin{array}{c}\text { A431 human } \\
\text { epidermoid carcinoma } \\
\text { cells }\end{array}$ & [116] \\
\hline EphrinA I & EphA2 receptor & $\begin{array}{l}\text { PC-3 human prostate } \\
\text { cancers }\end{array}$ & [117] \\
\hline \multirow[t]{7}{*}{$\begin{array}{c}\text { Transferrin } \\
\text { (apotransferrin) }\end{array}$} & TfR & $\begin{array}{c}\text { K562 human leukemia } \\
\text { cells }\end{array}$ & [118] \\
\hline & & $\begin{array}{l}\text { K562 > MV4-11 > Raji } \\
\text { human leukemia cells }\end{array}$ & [44] \\
\hline & & $\begin{array}{l}\text { LLC1 mouse lung cancer } \\
\text { cells }\end{array}$ & [119] \\
\hline & & $\begin{array}{l}\text { ZH5 rat hepatocellular } \\
\text { carcinoma cells }\end{array}$ & [120] \\
\hline & & $\begin{array}{c}\text { Ramos human Burkitt's } \\
\text { lymphoma cells }\end{array}$ & [109] \\
\hline & & $\begin{array}{c}\text { HepG2 human } \\
\text { hepatocellular } \\
\text { carcinoma cells }\end{array}$ & [121] \\
\hline & & $\begin{array}{l}\text { SCC-7 murine squamous } \\
\text { cell carcinoma cells }\end{array}$ & [122] \\
\hline $\begin{array}{l}\text { Urokinase plasminogen } \\
\text { activator (uPA) }\end{array}$ & uPA receptor (UPAR) & $\begin{array}{l}\text { MIA PaCa-2 human } \\
\text { pancreatic cancer cells }\end{array}$ & [123] \\
\hline VEGF121 & VEGF receptor & U87 human glioma cells & {$[124]$} \\
\hline
\end{tabular}




\begin{tabular}{c}
\hline Ligands \\
Peptides \\
Analogue peptide of \\
neuropeptide Y \\
(Arg6, Pro34) \\
Angiopep-2 \\
(TFFYGGSGKRNFKTEEY \\
$\alpha$-conotoxin ImI \\
(S-melanocyte-stimulating \\
hormone peptide \\
(SYSMEHFRWGKPV) \\
apoA-1 mimetic peptide \\
(AP) \\
(FAEKFKEAVKDYFAKFWD) \\
ATF peptide (amino acids 1 \\
to 135 of mouse uPA) \\
Bombesin (BN) peptide \\
(QWAVGHL) \\
Chlorotoxin [a 36-amino \\
acid peptide derived from \\
Leiurus quinquestriatus \\
(scorpion) venom]
\end{tabular}

Cyclic RGD

C16Y peptide (DFKLFAVYIKYR)

(D-Lys6)-LHRH

Follicle-stimulating hormone (FSH) $\beta$ 81-95 peptide

F3 peptide

$$
\text { Y1-receptor }
$$

Low-density

lipoprotein receptorrelated protein-1

$\alpha 7$ nicotinic acetylcholine receptor ( $\alpha 7 \mathrm{nAChR})$

Melanocortin type 1 receptor

\section{EGFR}

$$
\text { UPAR }
$$

Gastrin releasing peptide receptor

MMP-2 and receptorassociated protein

ClC-3

$$
\text { Integrin } \alpha_{v} \beta_{3}
$$

$$
\text { Integrin } \alpha_{\mathrm{v}} \beta_{3}
$$

Luteinizing hormonereleasing hormone (LHRH) receptor

FSH receptor

Nucleolin receptor
Target cancer cells

Refs.
MCF-7 human breast cancer cells

C6 rat glioma / U87 human glioma cells

MCF-7 human breast cancer cells

B16F0 mouse melanoma cells

KB human epidermoid carcinoma cells

MIA PaCa-2 human pancreatic cancer cells

HeLa human epidermoid carcinoma cells

U89 human glioma/C6 rat glioma cells

4T1 mouse metastatic breast cancer cells

M21 human melanoma cells

LNCaP human prostate cancer cells

SW620 human colon cancer cells

U87 human glioma cells

B16 mouse melanoma cells

A2780 human ovarian cancer cells

Caov-3 human ovarian cancer cells

MDA-MB-435S, MDAMB-231, and Hs578T 


\section{\begin{tabular}{c}
\hline Ligands \\
\hline PEPKPKKAPAKK) \\
Gastrin (modified peptide; \\
CKSSEAYGW-Nle-DF)
\end{tabular} \\ GE11 peptide \\ (CYHWYGYTPQNVI)}

HAIYPRH (knor-specific peptide)

Human ATF (hATF) peptide Interleukin 13 (IL-13) peptide (isolated by phage display; CGEMGWVRC)

iRGD (neuropilin 1-binding peptide; CRGDKGPDC)

MC1R agonist peptide (SYSNle-EH- $d$-FRWGKPV)

NR7 peptide (NSVRGSR)

PreS1-derived peptide

RGD

RGDGSSV

YCDGFYACYMDV

YCDPC

YIGSR (laminin-derived peptide)
Integrin $\alpha_{4} \beta_{1}$

Cholecystokinin-2 receptor EGFR

TfR

UPAR

IL-13R $\alpha 2$

Neuropilin 1

Melanocortin type-1 receptor (MC1R)

EGFR

Asialoglycoprotein
receptor

Vascular endothelial growth factor receptor-2 (VEGF R2)

Integrin $\alpha_{2 \mathrm{~b}} \beta_{3}$

HER2

Laminin receptor
Target cancer cells

Refs.

human breast cancer

cells

InR1G9 hamster

glucagonoma cells

HuH7 human

hepatocellular

carcinoma cells

[145]

Bel-7402 human

hepatocellular

[146]/

[147]

carcinoma/U87 human

glioma cells

MIA PaCa-2 human

pancreatic cancer cells

[148]

U87 human glioma/C6

rat glioma cells

[149]/

[150]

AsPC-1 human

pancreatic cancer cells

B16F0 / M3 mouse

melanoma cells

[151]

[152]/

SKOV-3 human ovarian cancer cells

HepaRG human

hepatocellular

carcinoma cells

N2A mouse

neuroblastoma cells

GL261 mouse glioma cell / B16F0 mouse melanoma cells

SK-BR-3 human breast cancer cells
KCl-H929 and MM.1S human multiple myeloma cells

[158]

[158]

B16 mouse melanoma cells 
\begin{tabular}{c}
\hline Ligands \\
\hline YSA peptide \\
(YSAYPDSVPMMS; mimics \\
the ligand ephrin-A1) \\
Others (small molecules)
\end{tabular}

Anisamide

Chondroitin sulfate

Folate
Sigma receptor

CD44 receptor

Folate receptor

$$
\begin{aligned}
& \text { NCI-H460 human lung } \\
& \text { cancer cells } \\
& \text { B16F0 mouse melanoma } \\
& \text { cells }
\end{aligned}
$$

H460 human non-small lung cancer cells

B16F0 mouse melanoma cells

KB human epidermoid carcinoma cells

[37-

HeLa human epidermoid carcinoma cells

9L / LacZ rat gliosarcoma cells

IGROV-1/SKOV-3 human ovarian cancer cells

B16 mouse melanoma cells

HepG2 human hepatocellular carcinoma cells

SKOV-3TR human ovarian cancer cells

Asialoglycoprotein receptor HepG2 human hepatocellular carcinoma cells

$$
\text { CD22 }
$$
glycoprotein glycan)

Pectin
Asialoglycoprotein receptor
Daudi human B-cell lymphoma cells

HepG2 human hepatocellular carcinoma cells 


\begin{tabular}{cccc}
\hline Ligands & Receptors & Target cancer cells & Refs. \\
\hline Tamoxifen derivative & Estrogen receptor & MCF-7 human breast & [171] \\
& cancer cells & \\
$\begin{array}{c}\text { Tetraiodothyroacetic acid } \\
\left(\alpha_{\mathrm{v}} \beta_{3} \text {-antagonist }\right)\end{array}$ & Integrin $\alpha_{\mathrm{v}} \beta_{3}$ & A375 human melanoma & [172] \\
\hline
\end{tabular}

\section{ACKNOWLEDGEMENTS}

This work was supported by a Health Labour Sciences Research Grant (Research on Publicly Essential Drugs and Medical Devices) from the Ministry of Health, Labour and Welfare of Japan; Special Coordination Funds for Promoting Science and Technology (SCF funding program "Innovation Center for Medical Redox Navigation"), and a Grant-in Aid for Scientific Research (No. 24300172) from the Ministry of Education, Culture, Sports, Science and Technology of Japan.

\section{REFERENCES}

1. B.W. Stewart, C.P. Wild, World Cancer Report 2014, IARC Publisher, Lyon, France, 2014, p. 16.

2. J. Ferlay, I. Soerjomataram, R. Dikshit, S. Eser, C. Mathers, M. Rebelo, D.M. Parkin, D. Forman, F. Bray. Int. J. Cancer 136 (2015) E359-E386.

3. M. Vanneman, G. Dranoff. Nat. Rev. Cancer 12 (2012) 237-251.

4. $\quad$ R. Baskar, K.A. Lee, R. Yeo, K.W. Yeoh. Int. J. Med. Sci. 9 (2012) 193-199.

5. V.T. DeVita. Cancer Res. 68 (2008) 8643-8653.

6. J.H. Kang, R. Toita, Y. Katayama. Biotechno. Adv. 28 (2012) 757-763.

7. S. Biswas, V.P. Torchilin. Adv. Drug Deliv. Rev. 66 (2014) 26-41.

8. S.A. Collines, B.A. Guinn, P.T. Harrison, M.F. Scallan, G.C. O’Sullivan, M. Tangney. Curr. Gene Ther. 8 (2008) 866-878.

9. $\quad$ M.Z.I. Pranjol, A. Hajitou. Viruses 7 (2015) 268-284.

10. R. Waehler, S.J. Russell, D.T. Curiel. Nat. Rev. Genetics 8 (2007) 573-587.

11. Y. Zhang, A. Satterlee, L. Huang. Mol. Ther. 20 (2012) 1298-1304.

12. X. Guo, L. Huang. Acc. Chem. Res. 45 (2012) 971-979.

13. N. Nair, T. Kasai, M. Seno. Anticancer Res. 34 (2014) 6289-6296.

14. R.S. Kerbel. N. Engl. J. Med. 358 (2008) 2039-2049.

15. S.M. Weis, D.A. Cheresh. Nat. Med. 17 (2011) 1359-1370.

16. Y. Matsumura, H. Maeda. Cancer Res. 46 (1986) 6387-6392.

17. U. Prabhakar, H. Maeda, R.K. Jain, E.M. Sevick-Muraca, W. Zamboni, O.C. Farokhzad, S.T. Barry, A. Gabizon, P. Grodzinski, D.C. Blakey. Cancer Res. 73 (2013) 1-6.

18. M. Longmire, P.L. Choyke, H. Kobayashi. Nanomedicine 3 (2008) 703-717.

19. H. Kobayashi, R. Watanabe, P.L. Choyke. Theranostics 4 (2014) 81-89. 
20. H. Maeda H. Nakamura, J. Fang. Adv. Drug Deliv. Rev. 65 (2013) 71-79.

21. H.S. Choi, W. Liu, P. Misra, E. Tanaka, J.P. Zimmer, B. Itty Ipe, M.G. Bawendi, J.V. Frangioni. Nat. Biotechnol. 25 (2007) 1165-1170.

22. F. Yuan, M. Dellian, D. Fukumura, M. Leunig, D.A. Berk, V.P. Torchilin, R.K. Jain. Cancer Res. 55 (1995) 3752-3756.

23. T.M. Allen, P.R. Cullis. Science 303 (2004) 1818-1822.

24. Y. Noguchi, J. Wu, R. Duncan, J. Strohalm, K. Ulbrich, T. Akaike, H. Maeda. Jpn. J. Cancer Res. 89 (1998) 307-314.

25. H. Imoto, Y. Sakamura, K. Ohkouchi, R. Atsumi, Y. Takakura, H. Sezaki, M. Hashida. Cancer Res. 52 (1992) 4396-4401.

26. C. He, Y. Hu, L. Yin, C. Tang, C. Yin. Biomaterials 31 (2010) 3657-3666.

27. E. Zwick, J. Bange, A. Ullrich. Endocr. Relat. Cancer 8 (2001)161-173.

28. A. Tomas, C.E. Futter, E.R. Eden. Trends Cell Biol. 24 (2014) 26-34.

29. R.T. Dorsam, J.S. Gutkind. Nat. Rev. Cancer 7 (2007) 79-94.

30. S. Wang, W.S. Ei-Deiry. Oncogene 22 (2003) 8628-8633.

31. K.M. Debatin, P.H. Krammer. Oncogene 23 (2004) 2950-2966.

32. M.E. Guicciardi, G.J. Gores. FASEB J. 23 (2009) 1625-1637.

33. K.M. McNeeley, E. Karathanasis, A.V. Annapragada, R.V. Bellamkonda. Biomaterials 30 (2009) 3986-3995.

34. N. Kamaly, T. Kalber, M. Thanou, J.D. Bell, A.D. Miller. Bioconjug. Chem. 20 (2009) 648-655.

35. J.C. Fernandes, X. Qiu, F.M. Winnik, M. Benderdour, X. Zhang, K. Dai, Q. Shi. Int. J. Nanomedicine 7 (2012) 5833-5845.

36. L. Wang, M. Li, N. Zhang. Int. J. Nanomedicine 7 (2012) 3281-3294.

37. P.J. Stevens, M. Sekido, R.J. Lee. Pharm. Res. 21 (2004) 2153-2157.

38. R. Rossin, D. Pan, K. Qi, J.L. Turner, X. Sun, K.L. Wooley, M.J. Welch. J. Nucl. Med. 46 (2005) 1210-1218.

39. G. Destito, R. Yeh, C.S. Rae, M.G. Finn, M. Manchester. Chem Biol. 14 (2007) 1152-1162.

40. A.J. Ditto, K.N. Shah, N.K. Robishaw, M.J. Panzner, W.J. Youngs, Y.H. Yun. Mol. Pharm. 9 (2012) 3089-3098.

41. F. Gao, L. Li, T. Liu, N. Hao, H. Liu, L. Tan, H. Li, X. Huang, B. Peng, C. Yan, K. Yang, X. Wu, D. Chen, F. Tang. Nanoscale 4 (2012) 3365-3372.

42. K.D. Lee, S.H. Choi, D.H. Kim, H.Y. Lee, K.C. Choi. Arch. Pharm. Res. 37 (2014) 1546-1553.

43. Y.Q. Guan, Z. Zheng, Z. Huang, Z. Li, S. Niu, J.M. Liu. Sci. Rep. 4 (2014) 4990.

44. X. Yang, C.G. Koh, S. Liu, X. Pan, R. Santhanam, B. Yu, Y. Peng, J. Pang, S. Golan, Y. Talmon, Y. Jin, N. Muthusamy, J.C. Byrd, K.K. Chan, L.J. Lee, G. Marcucci, R.J. Lee. Mol. Pharm. 6 (2009) 221-230.

45. A. Gautam, P. Kapoor, K Chaudhary, R. Kumar; Open Source Drug Discovery Consortium, G. P. Raghava. Curr. Med. Chem. 21 (2014) 2367-2391.

46. J. Bábíčková, L. Tóthová, P. Boor, P. Celec. Biotechnol. Adv. 31 (2013) 1247-1259.

47. A. Rivinoja, P. Laakkonen. Methods Mol. Biol. 683 (2011) 401-415.

48. R. Toita, M. Murata, S. Tabata, K. Abe, S. Narahara, J.S. Piao, J.H. Kang, M. Hashizume. Bioconjug. Chem. 23 (2012) 1494-1501.

49. F. Jing, D. Li, W. Xu, Y. Liu, K. Wang, Z. Sui. Pharm. Biol. 52 (2014) 570-574.

50. Q. Xu, Y. Liu, S. Su, W. Li, C. Chen, Y. Wu. Biomaterials 33 (2012) 1627-1639. 
51. X. Li, H. Zhou, L. Yang, G. Du, A.S. Pai-Panandiker, X. Huang, B. Yan. Biomaterials 32 (2011) 2540-2545.

52. H. Gao, Y. Xiong, S. Zhang, Z. Yang, S. Cao, X. Jiang. Mol. Pharm. 11 (2014) 1042-1052.

53. D.B. Kirpotin, D.C. Drummond, Y. Shao, M.R. Shalaby, K. Hong, U.B. Nielsen, J.D. Marks, C.C. Benz, J.W. Park. Cancer Res. 66 (2006) 6732-6740.

54. D.W. Bartlett, H. Su, I.J. Hildebrandt, W.A. Weber, M.E. Davis. Proc. Natl. Acad. Sci. USA 104 (2007) 15549-15554.

55. C.H. Choi, C.A. Alabi, P. Webster, M.E. Davis. Proc. Natl. Acad. Sci. USA 107 (2010) 1235-1240.

56. C. López-Otín, T. Hunter. Nat. Rev. Cancer 10 (2010) 278-292.

57. P.J. Utz, P. Anderson. Cell Death Differ. 7 (2000) 589-602.

58. O. Konopatskaya, A.W. Poole. Trends Pharmacol. Sci. 31 (2010) 8-14.

59. J.H. Kang. New J. Sci. 2014 (2014) 231418.

60. S. Naviglio, M. Caraglia, A. Abbruzzese, E. Chiosi, D. Di Gesto, M. Marra, M. Romano, A. Sorrentino, L. Sorvillo, A. Spina, G. Illiano. Expert. Opin. Ther. Targets 13 (2009) 83-92.

61. J.H. Kang, D. Asai, J.H. Kim, T. Mori, R. Toita, T. Tomiyama, Y. Asami, J. Oishi, Y.T. Sato, T. Niidome, B. Jun, H. Nakashima, Y. Katayama. J. Am. Chem. Soc. 130 (2008) 14906-14907.

62. J.H. Kang, J. Oishi, J.H. Kim, M. Ijuin, R. Toita, B. Jun, D. Asai, T. Mori, T. Niidome, K. Tanizawa, S. Kuroda, Y. Katayama. Nanomedicine 6 (2010) 583-589.

63. R. Toita, J.H. Kang, J.H. Kim, T. Tomiyama, T. Mori, T. Niidome, B. Jun, Y. Katayama. J. Control. Release 139 (2009) 133-139.

64. R. Toita, J.H. Kang, T. Tomiyama, C.W. Kim, S. Shiosaki, T. Niidome, T. Mori, Y. Katayama. J. Am. Chem. Soc. 134 (2012) 15410-15417.

65. T. Tomiyama, R. Toita, J.H. Kang, D. Asai, S. Shiosaki, T. Mori, T. Niidome, Y. Katayama. J. Control. Release 148 (2010) 101-105.

66. J. Oishi, K. Kawamura, J.H. Kang, K. Kodama, T. Sonoda, M. Murata, T. Niidome, Y. Katayama. J. Control. Release 110 (2006) 431-436.

67. B.S. Lee, Y.W. Cho, G.C. Kim, D.H. Lee, C.J. Kim, H.S. Kil, D.Y. Chi, Y. Byun, S.H. Yuk, K. Kim, I.S. Kim, I.C. Kwon, S.Y. Kim. J. Natl. Cancer Inst. In press. doi: 10.1093/jnci/dju403.

68. K. KIessenbrock, V. Plaks, Z. Werb. Cell 141 (2010) 52-67.

69. C. Gialeli, A.D. Theocharis, N. Karamanos. FEBS J. 278 (2011) 16-27.

70. L. Zhu, T. Wang, F. Perche, A. Taigind, V.P. Torchilin. Proc. Natl. Acad. Sci. USA 110 (2013) 17047-17052.

71. D. Bacinello, E. Garanger, D. Taton, K.C. Tam, S. Lecommandoux. Biomacromolecules 15 (2014) 1882-1888.

72. C. Nazli, G.S. Demirer, Y. Yar, H.Y. Acar, S. Kizilel. Colloids Surf. B Biointerfaces 122 (2014) 674-683.

73. F.B. Cui, R.T. Li, Q. Liu, P.Y. Wu, W.J. Hu, G.F. Yue, H. Ding, L.X. Yu, X.P. Qian, B.R. Liu. Cancer Lett. 346 (2014) 53-62.

74. T. Kawano, M. Murata, J.S. Piao, S. Narahara, N. Hamano, J.H. Kang, M. Hashizume. Int. J. Mol. Sci. 16 (2015) 148-158.

75. W.R. Wilson, M.P. Hay. Nat. Rev. Cancer 11, (2011) 393-410.

76. J.M. Brown, W.R. Wilson. Nat. Rev. Cancer 4 (2004) 437-447.

77. X. Zhao, F. Li, Y. Li, H. Wang, H. Ren, J. Chen, G. Nie, J. Hao. Biomaterials 46 (2015) 13-25. 
78. X.Q. Liu, M.H. Xiong, X.T. Shu, R.Z. Tang, J. Wang. Mol. Pharm. 9 (2012) 2863-2874.

79. W.H. Chen, R.L. Lecaros, Y.C. Tseng, L. Huang, Y.C. Hsu. Cancer Lett. 359 (2015) 65-74.

80. Y. Wang, M. Saad, R.I. Pakunlu, J.J. Khandare, O.B. Garbuzenko, A.A. Vetcher, V.A. Soldatenkov, V.P. Pozharov, T. Minko. Clin. Cancer Res. 14 (2008) 607-616.

81. R.L. Cowen, E.J. Garside, B. Fitzpatrick, M.V. Papadopoulou, K.J. Williams. Br. J. Radiol. 81 (2008) S45-S56.

82. P.B. Card, R.T. Hogg, C.R. Gil Del Alcazar, R.D. Gerard. Cancer Gene Ther. 19 (2012) 451-459.

83. T. Thambi, V.G. Deepagan, H.Y. Yoon, H.S. Han, S.H. Kim, S. Son, D.G. Jo, C.H. Ahn, Y.D. Suh, K. Kim, I.C. Kwon, D.S. Lee, J.H. Park. Biomaterials 35 (2014) 1735-1743.

84. O. Mazuryk, M. Maciuszek, G. Stochel, F. Suzenet, M. Brindell. J. Inorg. Biochem. 134 (2014) 83-91.

85. C. Bettegowda, L.H. Dang, R. Abrams, D.L. Huso, L. Dillehay, I. Cheong, N. Agrawal, S. Borzillary, K.M. McCaffery, E.L. Watson, K.S. Lin, F. Bunz, K. Baidoo, M.G. Pomper, K.W. Kinzler, B. Vogelstein, S. Zhou. Proc. Natl. Acad. Sci. USA 9 (2003) 15083-15088.

86. C.H. Lee, C.L. Wu, Y.S. Tai, A.L. Shiau. Mol. Ther. 11 (2005) 707-716.

87. M.Q. Wei, R. Ren, D. Good, J. Anné. Genet. Vaccines Ther. 6 (2008) 8.

88. B. Yu, M. Yang, L. Shi, Y. Yao, Q. Jiang, X. Li, L. H. Tang, B.J. Zheng, K.Y. Yuen, D.K. Smith, E. Song, J.D. Huang. Sci. Rep. 2 (2012) 436.

89. S. Taniguchi, M. Fujimori, T. Sasaki, H. Tsutsui, Y. Shimatani, K. Seki, J. Amano. Cancer Sci. 101 (2010) 1925-1932.

90. K.B. Low, M. Ittensohn, T. Le, J. Platt, S. Sodi, M. Amoss, O. Ash, E. Carmichael, A. Chakraborty, J. Fischer, S.L. Lin, X. Luo, S.I. Miller, L. Zheng, I. King, J.M. Pawelek, D. Bermudes. Nat. Biotechnol. 17 (1999) 37-41.

91. V. Punj, D. Saint-Dic, S. Daghfal, J.R. Kanwar. Cancer Biol. Ther. 3 (2004) 708-714.

92. T. Mori, J.H. Kang, in Breakthroughs in melanoma research, Y. Tanaka (Ed.), InTech Publisher, Rijeka, Croatia, 2012, p. 389.

93. A.S. Thakor, S.S. Gambhir. CA Cancer J. Clin. 63 (2013) 395-418.

94. R.K. Jain, T. Stylianopoulos. Nat. Rev. Clin. Oncol. 7 (2010) 653-664.

95. Y. Barenholz. J. Control. Release 160 (2012) 117-134.

96. L. Paz-Ares, H. Ross, M. O'Brien, A. Riviere, U. Gatzemeier, J. Von Pawel, E. Kaukel, L. Freitag, W. Digel, H. Bischoff, R. García-Campelo, N. Iannotti, P. Reiterer, I. Bover, J. Prendiville, A.J. Eisenfeld, F.B. Oldham, B. Bandstra, J.W. Singer, P. Bonomi. Br. J. Cancer 98 (2008) 1608-1613.

97. M.E. O'Brien, M.A. Socinski, A.Y. Popovich, I.N. Bondarenko, A. Tomova, B.T. Bilynsky, Y.S. Hotko, V.L. Ganul, I.Y. Kostinsky, A.J. Eisenfeld, L. Sandalic, F.B. Oldham, B. Bandstra, A.B. Sandler, J.W. Singer. J. Thorac. Oncol. 3 (2008) 728-734.

98. G.J. Weiss, J. Chao, J.D. Neidhart, R.K. Ramanathan, D. Bassett, J.A. Neidhart, C.H. Choi, W. Chow, V. Chung, S.J. Forman, E. Garmey, J. Hwang, D.L. Kalinoski, M. Koczywas, J. Longmate, R.J. Melton, R. Morgan, J. Oliver, J.J. Peterkin, J.L. Ryan, T. Schluep, T.W. Synold, P. Twardowski, M.E. Davis, Y. Yen. Invest. New Drugs 31 (2013) 986-1000. 
99. A. Awada, A.A. Garcia, S. Chan, G.H. Jerusalem, R.E. Coleman, M.T. Huizing, A. Mehdi, S.M. O'Reilly, J.T. Hamm, P.J. Barrett-Lee, V. Cocquyt, K. Sideras, D.E. Young, C. Zhao, Y.L. Chia, U. Hoch, A.L. Hannah, E.A. Perez. Lancet Oncol. 14 (2013) 1216-1225.

100. N. Senzer, J. Nemunaitis, D. Nemunaitis, C. Bedell, G. Edelman, M. Barve, R. Nunan, K.F. Pirollo, A. Rait, E.H. Chang. Mol. Ther. 21 (2013) 1096-1103.

101. M.E. Davis, J.E. Zuckerman, C.H. Choi, D. Seligson, A. Tolcher, C.A. Alabi, Y. Yen, J.D. Heidel, A. Ribas. Nature 464 (2010)1067-1070.

102. A. Cirstoiu-Hapca, L. Bossy-Nobs, F. Buchegger, R. Gurny, F. Delie. Int. J. Pharm. 331 (2007) 190-196.

103. A.E. Felber, B. Castagner, M. Elsabahy, G.F. Deleavey, M.J. Damha, J.C. Leroux. J. Control. Release 152 (2011) 159-167.

104. S.M. Abdelghany, D. Schmid, J. Deacon, J. Jaworski, F. Fay, K.M. McLaughlin, J.A. Gormley, J.F. Burrows, D.B. Longley, R.F. Donnelly, C.J. Scott. Biomacromolecules 14 (2013) 302-310.

105. B. Ding, X. Wu, W. Fan, Z. Wu, J. Gao, W. Zhang, L. Ma, W. Xiang, Q. Zhu, J. Liu, X. Ding, S. Gao. Int. J. Nanomedicine 6 (2011) 1991-2005.

106. Y. Liu, K. Li, B. Liu, S.S. Feng. Biomaterials 31 (2010) 9145-9155.

107. R. Heukers, I. Altintas, S. Raghoenath, E. De Zan, R. Pepermans, R.C. Roovers, R. Haselberg, W.E. Hennink, R.M. Schiffelers, R.J. Kok, P.M. van Bergen en Henegouwen. Biomaterials 35 (2014) 601-610.

108. X.H. Peng, Y. Wang, D. Huang, Y. Wang, H.J. Shin, Z. Chen, M.B. Spewak, H. Mao, X. Wang, Y. Wang, Z.G. Chen, S. Nie, D.M. Shin. ACS Nano 5 (2011) 9480-9493.

109. J. Wang, S. Tian, R.A. Petros, M.E. Napier, J.M. Desimone. J. Am. Chem. Soc. 132 (2010) 11306-11313.

110. T. Chen, M.I. Shukoor, R. Wang, Z. Zhao, Q. Yuan, S. Bamrungsap, X. Xiong, W. Tan. ACS Nano 5 (2011) 7866-7873.

111. L. Cerchia, C.L. Esposito, S. Camorani, A. Rienzo, L. Stasio, L. Insabato, A. Affuso, V. de Franciscis. Mol. Ther. 20 (2012) 2291-303.

112. M.Z. Zhang, R.N. Yu, J. Chen, Z.Y. Ma, Y.D. Zhao. Nanotechnology 23 (2012) 485104.

113. S. Díez, G. Navarro, C.T. de ILarduya. J. Gene Med. 11 (2009) 38-45.

114. Y.C. Yao, X.Y. Zhan, J. Zhang, X.H. Zou, Z.H. Wang, Y.C. Xiong, J. Chen, G.Q. Chen. Biomaterials 29 (2008) 4823-4830.

115. M.A. Sandoval, B.R. Sloat, D.S. Lansakara, A. Kumar, B.L. Rodriguez, K. Kiguchi, J. Digiovanni, Z. Cui. J. Control. Release 157 (2012) 287-296.

116. C. Fortier, G. De Crescenzo, Y. Durocher. Biomaterials 34 (2013) 1344-1353.

117. A.M. Gobin, J.J. Moon, J.L. West. Int. J. Nanomedicine 3 (2008) 351-358.

118. N.C. Bellocq, S.H. Pun, G.S. Jensen, M.E. Davis. Bioconjug. Chem. 14 (2003) 1122-1132.

119. R.A. Abela, J. Qian, L. Xu, T.S. Lawrence, M. Zhang. Cancer Gene Ther. 15 (2008) 496-507.

120. A.D. Krishna, R.K. Mandraju, G. Kishore, A.K. Kondapi. PLoS One 4 (2009) e7240.

121. W. Wang, F. Zhou, L. Ge, X. Liu, F. Kong. Int. J. Nanomedicine 7 (2012) 2513-2522.

122. J.Y. Yhee, S.J. Lee, S. Lee, S. Song, H.S. Min, S.W. Kang, S. Son, S.Y. Jeong, I.C. Kwon, S.H. Kim, K. Kim. Bioconjug. Chem. 24 (2013) 1850-1860. 
123. G.Y. Lee, W.P. Qian, L. Wang, Y.A. Wang, C.A. Staley, M. Satpathy, S. Nie, H. Mao, L. Yang. ACS Nano 7 (2013) 2078-2089.

124. S. Goel, F. Chen, H. Hong, H.F. Valdovinos, R. Hernandez, S. Shi, T.E. Barnhart, W. Cai. ACS Appl. Mater. Interfaces 6 (2014) 21677-21685.

125. W. Hild, K. Pollinger, A. Caporale, C. Cabrele, M. Keller, N. Pluym, A. Buschauer, R. Rachel, J. Tessmar, M. Breunig, A. Goepferich. Proc. Natl. Acad. Sci. USA 107 (2010) 10667-10672.

126. R. Huang, W. Ke, L. Han, J. Li, S. Liu, C. Jiang. Biomaterials 32 (2011) 2399-2406.

127. L. Mei, Q. Zhang, Y. Yang, Q. He, H. Gao. Int. J. Pharm. 474 (2014) 95-102.

128. D. Mei, Z. Lin, J. Fu, B. He, W. Gao, L. Ma, W. Dai, H. Zhang, X. Wang, J. Wang, X. Zhang, W. Lu, D. Zhou, Q. Zhang. Biomaterials 42 (2015) 52-65.

129. L. Vannucci, E. Falvo, M. Fornara, P. Di Micco, O. Benada, J. Krizan, J. Svoboda, K. Hulikova-Capkova, V. Morea, A. Boffi, P. Ceci. Int. J. Nanomedicine 7 (2012) 1489-1509.

130. Z. Zhang, J. Chen, L. Ding, H. Jin, J.F. Lovell, I.R. Corbin, W. Cao, P.C. Lo, M. Yang, M.S. Tsao, Q. Luo, G. Zheng. Small 6 (2010) 430-437.

131. L. Yang, H. Mao, Z. Cao, Y.A. Wang, X. Peng, X. Wang, H.K. Sajja, L. Wang, H. Duan, C. Ni, C.A. Staley, W.C. Wood, X. Gao, S. Nie. Gastroenterology 136 (2009) 1514-1525.

132. L. Hosta-Rigau, I. Olmedo, J. Arbiol, L.J. Cruz, M.J. Kogan, F. Albericio. Bioconjug. Chem. 21 (2012) 1070-1078.

133. C. Qin, B. He, W. Dai, Z. Lin, H. Zhang, X. Wang, J. Wang, X. Zhang, G. Wang, L. Yin, Q. Zhang. Biomaterials 35 (2014) 5908-5920.

134. S. Huang, J. Li, L. Han, S. Liu, H. Ma, R. Huang, C. Jiang. Biomaterials 32 (2011) 6832-6838.

135. C. Qin, B. He, W. Dai, H. Zhang, X. Wang, J. Wang, X. Zhang, G. Wang, L. Yin, Q. Zhang. Mol. Pharm. 11 (2014) 3233-3241.

136. C.A. Boswell, P.K. Eck, C.A. Regino, M. Bernardo, K.J. Wong, D.E. Milenic, P.L. Choyke, M.W. Brechbiel. Mol. Pharm. 5 (2008) 527-539.

137. H.S. Choi, W. Liu, F. Liu, K. Nasr, P. Misra, M.G. Bawendi, J.V. Frangioni. Nat. Nanotechnol. 5 (2010) 42-47.

138. L. Li, J. Yang, W.W. Wang, Y.C. Yao, S.H. Fang, Z.Y. Dai, H.H. Hong, X. Yang, X.T. Shuai, G.Q. Gao. Int. J. Pharm. 438 (2012) 1-10.

139. Y. Zhong, C. Wang, R. Cheng, L. Cheng, F. Meng, Z. Liu, Z. Zhong. J. Control. Release 195 (2014) 63-71.

140. N. Hamano, Y. Negishi, A. Fujisawa, M. Manandhar, H. Sato, F. Katagiri, M. Nomizu, Y. Aramaki. Int. J. Pharm. 428 (2012) 114-117.

141. N.V. Nukolova, H.S. Oberoi, Y. Zhao, V.P. Chekhonin, A.V. Kabanov, T.K. Bronich. Mol. Pharm. 10 (2013) 3913-321.

142. X. Zhang, J. Chen, Y. Kang, S. Hong, Y. Zheng, H. Sun, C. Xu. Int. J. Pharm. 453 (2013) 498-505.

143. V. Moura, M. Lacerda, P. Figueiredo, M.L. Corvo, M.E. Cruz, R. Soares, M.C. de Lima, S. Simões, J.N. Moreira. Breast Cancer Res. Treat. 133 (2012) 61-73.

144. C. Sanchez, D. El Hajj Diab, V. Connord, P. Clerc, E. Meunier, B. Pipy, B. Payré, R.P. Tan, M. Gougeon, J. Carrey, V. Gigoux, D. Fourmy. ACS Nano 8 (2014) 1350-1363. 
145. F.M. Mickler, L. Möckl, N. Ruthardt, M. Ogris, E. Wagner, C. Bräuchle. Nano Lett. 12 (2012) 3417-3423.

146. L. Han, R. Huang, J. Li, S. Liu, S. Huang, C. Jiang. Biomaterials 32 (2011) 1242-1252.

147. Y. Kuang, S. An, Y. Guo, S. Huang, K. Shao, Y. Liu, J. Li, H. Ma, C. Jiang. Int. J. Pharm. 454 (2013) 11-20.

148. Y.S. Cho, G.Y. Lee, H.K. Sajja, W. Qian, Z. Cao, W. He, P. Karna, X. Chen, H. Mao, Y.A. Wang, L. Yang. Small 9 (2013) 1964-1973.

149. H. Gao, Z. Yang, S. Zhang, S. Cao, S. Shen, Z. Pang, X. Jiang. Sci. Rep. 3 (2013) 2534.

150. B. Wang, L. Lv, Z. Wang, Y. Zhao, L. Wu, X. Fang, Q. Xu, H. Xin. Biomaterials 35 (2014) 5897-5907.

151. M. Murata, S. Narahara, T. Kawano, N. Hamano, J.S. Piao, J.H. Kang, K. Ohuchida, T. Murakami, M. Hashizume. Mol. Pharm. 12 (2015) 1422-1430.

152. W. Lu, C. Xiong, R. Zhang, L. Shi, M. Huang, G. Zhang, S. Song, Q. Huang, G.Y. Liu, C. Li. J. Control. Release 161 (2012) 959-966.

153. M.O. Durymanov, E.A. Beletkaia, A.V. Ulasov, Y.V. Khramtsov, G.A. Trusov, N.S. Rodichenko, T.A. Slastnikova, T.V. Vinogradova, N.Y. Uspenskaya, E.P. Kopantsev, A.A. Rosenkranz, E.D. Sverdlov, A.S. Sobolev. J. Control. Release 163 (2012) 211-219.

154. C.W. Liu, W.J. Lin. Int. J. Nanomedicine 7 (2012) 4749-4767.

155. M. Murata, J.S. Piao, S. Narahara, T. Kawano, N. Hamano, J.H. Kang, D. Asai, R. Ugawa, M. Hashizume. Protein Expr. Purif. 110 (2015) 52-56.

156. R.M. Schiffelers, A. Ansari, J. Xu, Q. Zhou, Q. Tang, G, Storm, G. Molema, P.Y. Lu P.V. Scaria, M.C. Woodle. Nucleic Acids Res. 32 (2004) e149.

157. D. Hallahan, L. Geng, S. Qu, C. Scarfone, T. Giorgio, E. Donnelly, X. Gao, J. Clanton. Cancer Cell 3 (2003) 63-74.

158. J.F. Stefanick, J.D. Ashley, B. Bilgicer. ACS Nano 7 (2013) 8115-8127.

159. G. Sarfati, T. Dvir, M. Elkabets, R.N. Apte, S. Cohen. Biomaterials 32 (2011) 152-161.

160. W.H. Blackburn, E.B. Dickerson, M.H. Smith, J.F. McDonald, L.A. Lyon. Bioconjug. Chem. 20 (2009) 960-968.

161. S.D. Li, Y.C. Chen, M.J. Hackett, L. Huang. Mol. Ther. 16 (2008) 163-169.

162. Y. Yang, J. Li, F. Liu, L. Huang. Mol. Ther. 20 (2012) 609-615.

163. S.K. Kim, M.B. Foote, L. Huang. Cancer Lett. 334 (2013) 311-318.

164. T. Kurosaki, T. Kitahara, S. Kawakami, K. Nishida, J. Nakamura, M. Teshima, H. Nakagawa, Y. Kodama, H. Sasaki. Biomaterials 30 (2009) 4427-4434.

165. F.L. Mi, Y.Y. Wu, Y.L. Chiu, M.C. Chen, H.W. Sung, S.H. Yu, S.S. Shyu, M.F. Huang. Biomacromolecules 8 (2007) 892-898.

166. H.F. Liang, C.T. Chen, S.C. Chen, A.R. Kulkarni, Y.L. Chiu, M.C. Chen, H.W. Sung. Biomaterials 27 (2006) 2051-2059.

167. X. Yang, A.K. Lyer, A. Singh, E. Choy, F.J. Hornicek, M.M. Amiji, Z. Duan. Sci. Rep. 5 (2015) 8509.

168. X. Zhou, M. Zhang, B. Yung, H. Li, C. Zhou, L.J. Lee, R.J. Lee. Int. J. Nanomedicine 7 (2012) 5465-5474.

169. W.C. Chen, D.S. Sigal, A. Saven, J.C. Paulson. Leuk. Lymphoma. 53 (2012) 208-210.

170. C.Y. Yu, Y.M. Wang, N.M. Li, G.S. Liu, S. Yang, G.T. Tang, D.X. He, X.W. Tan, H. Wei. Mol. Pharm. 11 (2014) 638-644. 
171. E.C. Dreaden, S.C. Mwakwari, Q.H. Sodji, A.K. Oyelere, M.A. El-Sayed. Bioconjug. Chem. 20 (2009) 2247-2253.

172. S. Lee, J. Kim, G. Shim, S. Kim, S.E. Han, K. Kim, I.C. Kwon, Y. Choi, Y.B. Kim, C.W. Kim, Y.K. Oh. J. Control. Release 164 (2012) 213-220. 